\title{
Geotechnical and Mineralogical Properties of the Recently Exposed Black Mud Deposits along the Northeastern Shore of the Dead Sea
}

\author{
Waed Abu Alhaj', Elias Salameh² () \\ ${ }^{1}$ Department of Geology, University of Jordan, Amman, Jordan \\ ${ }^{2}$ Faculty of Science, University of Jordan, Amman, Jordan \\ Email:waed.abulhaj@gmail.com, salameli@ju.edu.jo
}

How to cite this paper: Alhaj, W.A. and Salameh, E. (2020) Geotechnical and Mineralogical Properties of the Recently Exposed Black Mud Deposits along the Northeastern Shore of the Dead Sea. Open Journal of Geology, 10, 943-956.

https://doi.org/10.4236/ojg.2020.108042

Received: July 28, 2020

Accepted: August 25, 2020

Published: August 28, 2020

Copyright $\odot 2020$ by author(s) and Scientific Research Publishing Inc. This work is licensed under the Creative Commons Attribution-NonCommercial International License (CC BY-NC 4.0). http://creativecommons.org/licenses/by-nc/4.0/ (c) (i) Open Access

\begin{abstract}
Along the recently evacuated shores of the retreating Dead Sea black mud deposits have been exposed and hence subjected to head ward erosion resulting in landslides and land collapses threatening herewith the infrastructure in the area. The geotechnical and mineralogical characterization of the black mud show the presence of a variety of clays including smectite, kaolinite, illite, montmorollinite and muscovite with a natural water content near the liquid limit. These geotechnical and mineralogical properties indicate that the mud is prone to rapid erosion and sliding, which actually hit the area and have until now caused damages and degrading topography and geology in the area. The study also refers the origin of the black mud and its organic content to the erosion and deposition of Upper Cretaceous-Tertiary oil shale deposits formerly covering the whole surrounding areas of the Dead Sea. The study suggests engineering solutions to the geologic degradation processes in the area, before further damage to the infrastructure takes place.
\end{abstract}

\section{Keywords}

Retreating Dead Sea, Land Collapses, Organic Mud in Hyper-Saline Water, Geological Engineering, Mineralogical Characteristics

\section{Introduction}

The retreat of the Dead Sea during the last five decades exposed new land and older coastal sediments formerly covered by Dead Sea (DS) water. Gravels, sands and rocks boulders build the sediments of the shores, further offshore, silt and clay sediments came to deposition. 
The wadis which formerly used to flow directly into the DS discharged at a DS level of approximately $-395 \mathrm{~m}$ in 1960s. Since then discharge levels have dropped simultaneously with the drop in the DS level, which caused cutting into the older coastal sediments. The topographic slopes between the older shore level and the present one gradually increased and became very high which allowed flood and base flows to incise deep wadis in the non-consolidated sediments of the older shore areas and to cause heavy degradation in the set-up of the area resulting in strong erosion, land collapses and landslides and sink hole formation, among others with all the ramifications to the infrastructure of the area [1] [2] [3] [4] [5].

This study focuses on the degradation processes and the geotechnical and mineralogical properties of the rocks leading to the geo-hazards in the area along the northeastern shore of the DS.

Engineering geological solutions are offered to rehabilitate the degrading geologic setup and to protect the infrastructure of roads, buildings, hotels, bridges, water culverts and farming lands.

\subsection{Methodology}

Field work was carried out to study the recent sediments, their extension and thickness, the recent deformation structures in them and to collect water and rock samples for laboratory analyses.

Laboratory testing was carried out at the laboratories of the University of Jordan and Halle University, Germany. The random XRD scanned the rock samples from $2^{\circ}$ to $60^{\circ}$, using $\mathrm{Cu}$, ka, (X-Ray Diffractometer SHIMADZU 7000) with computerized peak plots. SHIMADZU-1800 was used to quantitatively analyze the metal contents of the samples. Scanning electron microscopy (SEM) with a magnification of $>100,000 \mathrm{X}$ was used.

Compression tests were performed using DIN 18135 [6] for soil, investigation and testing. Samples were extracted in cylindrical sample tubes in the field and WilleGeotechnik equipment in the laboratory.

Direct shear tests were performed in a constant displacement sheer rate of $0.002 \mathrm{~mm} / \mathrm{min}$ using WilleGeotechnik, type: SL $100 \mathrm{z}$ using different normal stresses of 400,200 and $100 \mathrm{kPa}\left(1 \mathrm{~Pa}=1 \mathrm{~N} / \mathrm{m}^{2}\right)$.

Liquid and plastic limit tests were performed according to DIN 18122-1 [7] and permeability tests according to DIN 18130 [8], Soil investigation and testing. MicrotracZetatrac machine was used for particle size analysis.

\subsection{Location of the Study Area}

The study area is located along the northeastern shores of the DS between coordinates $31^{\circ} 44^{\prime} 15.56^{\prime \prime} \mathrm{N}$ to $31^{\circ} 47^{\prime} 50.05^{\prime \prime} \mathrm{N}$ and $35^{\circ} 35^{\prime} 34.13^{\prime \prime} \mathrm{E}$ to $35^{\circ} 36^{\prime} 15.13^{\prime \prime} \mathrm{E}$ (Figure 1 [9]). The topography of the area extending from the DS highway to the DS shore line varies in elevation from $390 \mathrm{mbsl}$ on the highway (The DS level during the 1960s was $395 \mathrm{mbsl}$ ) to $431 \mathrm{mbsl}$ at the present DS shore. It is a 

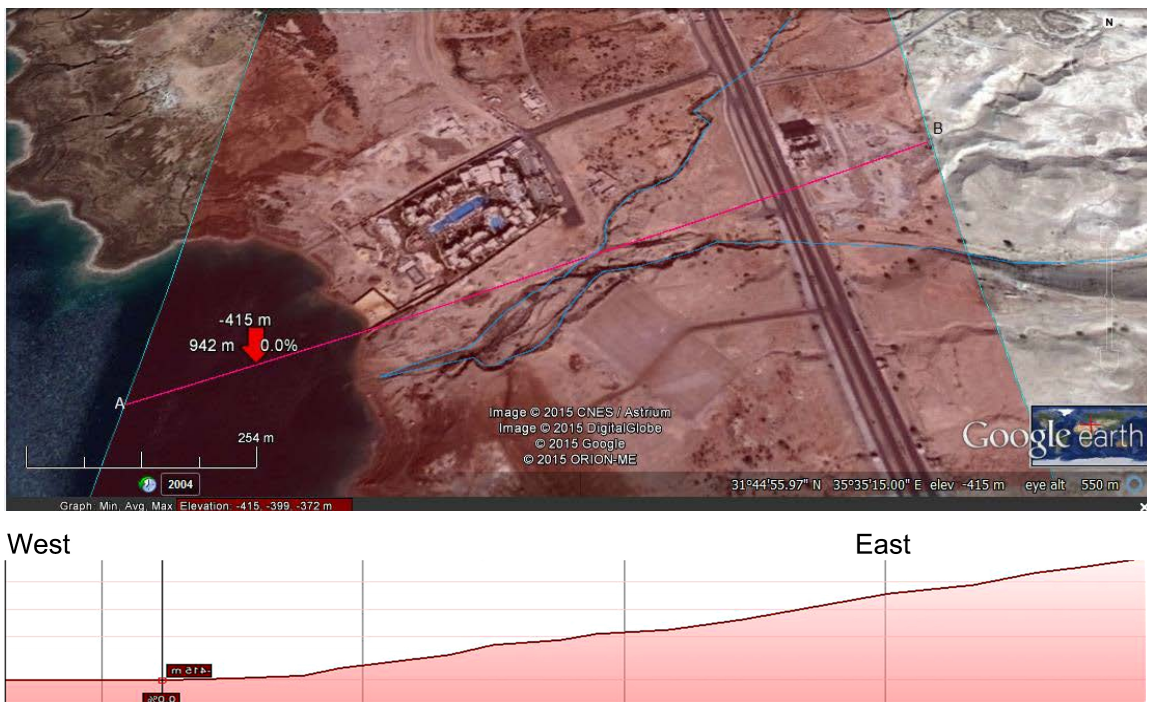

Figure 1. Location map of the study area at the northeastern shore of the Dead Sea together with a topographic E-W profile [9].

terrain dissected by many recent wadi courses, along which land collapses and landslides have developed.

\subsection{Geology}

The area is built of Pleistocene marl and clay (black mud) deposits of about $20 \mathrm{~m}$ exposed thickness covered by a few meters of recent gravels and sands.

\section{Mineralogical Analyses}

The mineralogy of whole samples collected from the study area were studied by using X-ray diffraction (XRD), X-ray fluorescence (XRF), Scanning Electron Microscopy (SEM) and particle size analysis.

\subsection{X-Ray Diffraction (XRD)}

X-Ray Diffraction (XRD) was carried out on two samples prepared by color separation; grey and black to analyze the mineral content of the black mud. The results are presented in Figure 2 and Table 1, which shows that the gray content is composed of aragonite, calcite, dolomite, gypsum, halite, halite potassium, illite, kaolinite, muscovite and quartz and does not contain anorthoclase and montmorillonite, whereas the black content is composed of aragonite, calcite, dolomite, gypsum, kaolinite, muscovite, montmorillonite and quartz and does not contain dolomite, halite, halite potassium and illite. X-Ray Diffraction (XRD) results (Figure 2) show that the main minerals in the samples are: Calcite, quartz, dolomite, muscovite, kaolinite, illite, smectite, halite and pyrite.

\subsection{X-Ray Fluorescence (XRF)}

The results of XRF are listed in Table 2 which shows that the clays mainly contain oxides of silicon, calcium, aluminum, iron, potassium and sodium and less 
than $1 \%$ of each of titanium, sulfur, phosphate, strontium manganese, barium chromium, rubidium zinc, nickel and copper

\subsection{Scanning Electron Microscope (SEM)}

Mud samples were scanned for their contents on clay minerals and to obtain microscopic SEM images of these clays. Figure 3 illustrates, as an example, the images of the studied mud samples showing kaolinite and the SEM analytical metal results.
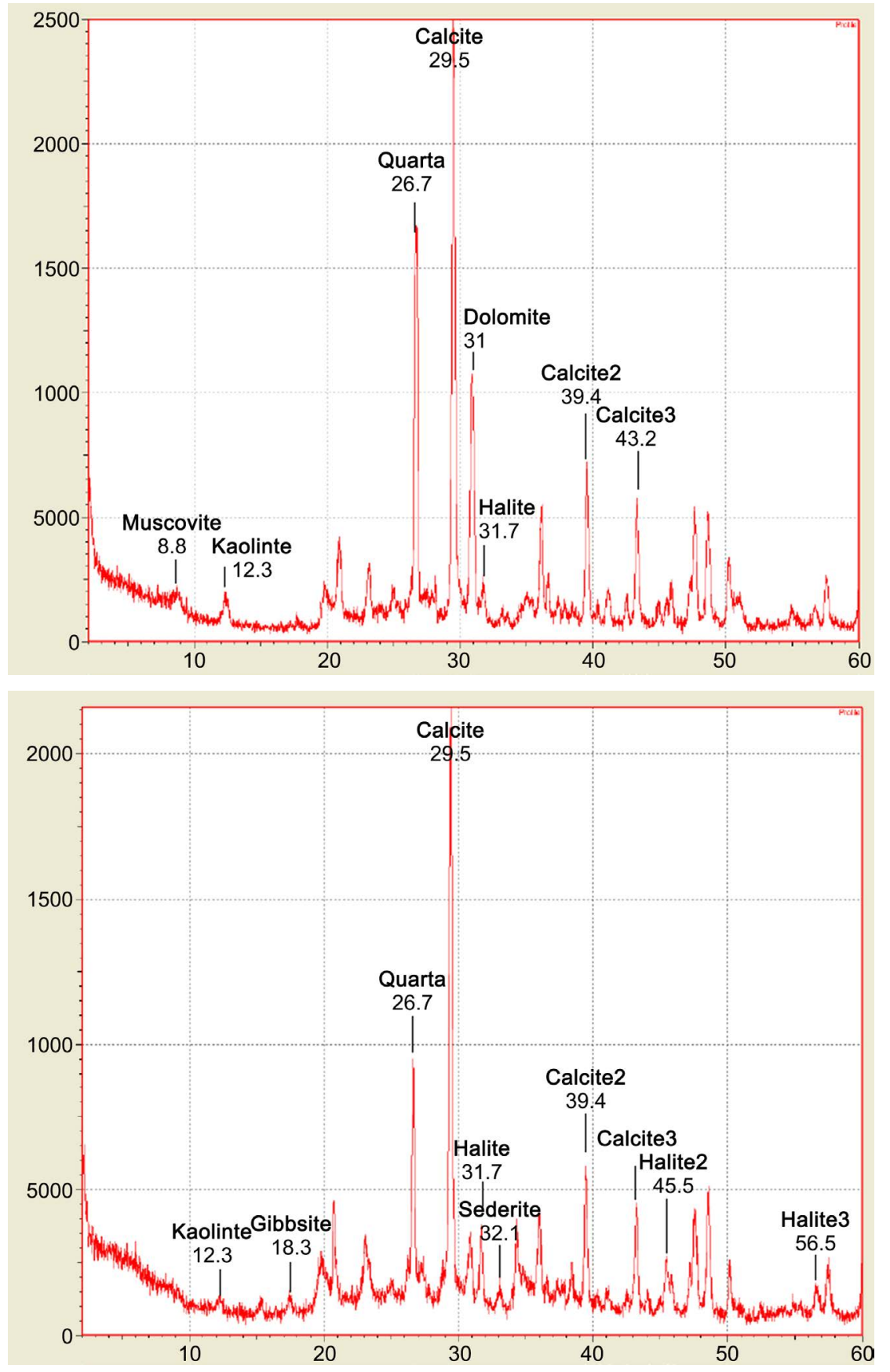

Figure 2. XRD of a black mud sample showing its mineral composition. 
Table 1. Qualitative mineral content of a grey and black mud samples obtained by using $\mathrm{XRF}(+$ means mineral was detected in the sample).

\begin{tabular}{ccc}
\hline & \multicolumn{3}{c}{ Dead Sea mud } \\
Mineral & Grey Content & Black Content \\
\cline { 2 - 3 } Aragonite & + & + \\
Anorthoclase & + & + \\
Calcite & + & + \\
Dolomite & + & \\
Gypsum & + & \\
Halite & + & + \\
Halite potassium & + & + \\
Illite & + & + \\
Kaolinite & + & + \\
Muscovite & + & + \\
Montmorillonite & + & + \\
Quartz & & +
\end{tabular}

Table 2. XRF result of representative mineral contents of Dead Sea mud samples.

\begin{tabular}{cccc}
\hline Compound & \% Content & Compound & \% Content \\
\hline $\mathrm{SiO}_{2}$ & 38.37 & $\mathrm{P}_{2} \mathrm{O}_{5}$ & 0.53 \\
$\mathrm{CaO}$ & 26.55 & $\mathrm{SrO}$ & 0.152 \\
$\mathrm{Al}_{2} \mathrm{O}_{3}$ & 14.37 & $\mathrm{MnO}$ & 0.075 \\
$\mathrm{MgO}$ & 7.67 & $\mathrm{BaO}$ & 0.043 \\
$\mathrm{Fe}_{2} \mathrm{O}_{3}$ & 5.55 & $\mathrm{Cr}_{2} \mathrm{O}_{3}$ & 0.035 \\
$\mathrm{~K}_{2} \mathrm{O}$ & 3.25 & $\mathrm{Rb}_{2} \mathrm{O}$ & 0.03 \\
$\mathrm{Na}_{2} \mathrm{O}$ & 1.5 & $\mathrm{ZnO}$ & 0.015 \\
$\mathrm{TiO}_{2}$ & 0.96 & $\mathrm{NiO}$ & 0.0113 \\
$\mathrm{SO}_{3}$ & 0.89 & $\mathrm{CuO}$ & 0.006 \\
\hline
\end{tabular}
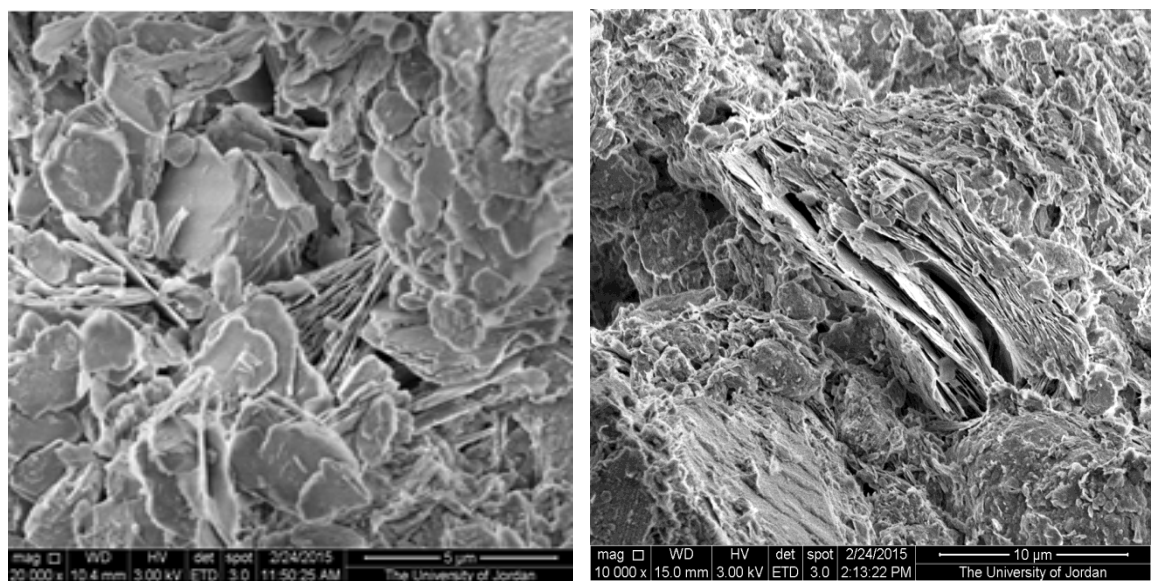

Figure 3. SEM image of kaolinite in the Dead Sea mud samples. 


\section{Engineering Properties}

Different geo-techniques, as detailed by [10] have been used to characterize the engineering properties of the Dead Sea mud. They are discussed in the following paragraphs. Engineering tests were carried out using DIN procedures Nos. 18135 [6], 18122-1 [7] and 18130 [8].

\subsection{Particle Size Analysis}

Particle size analysis tests show the following results (Figure 4):

- The Zeta Potential (MV) of the samples plotted in the range of incipient instability.

- All the samples lie in the clay range of $0.98 \mu \mathrm{m}-3.9 \mu \mathrm{m}$ and are very well-sorted according to their standard deviation of 0.09 [11].

- According to the values of skewness (Table 3), the Dead Sea black muds are found to be near symmetrical; +0.1 to -0.1 [11].

\subsection{Stress-Strain Tests}

The stress-strain tests show that the mud has not been exposed to pressure before and thence it has no pre-history of loading. The recovery after stress application was very minor as can be seen from the hysteresis (Figure 5).

\begin{tabular}{|c|c|}
\hline \multicolumn{2}{|c|}{ Zeta Potential } \\
\hline Mobility (u/s/V/cm): & 0.8100 \\
\hline Zeta Potential (mv): & 10.3600 \\
\hline Charge (fC): & 0.04600 \\
\hline Conductivity (uS/cm): & 691 \\
\hline
\end{tabular}

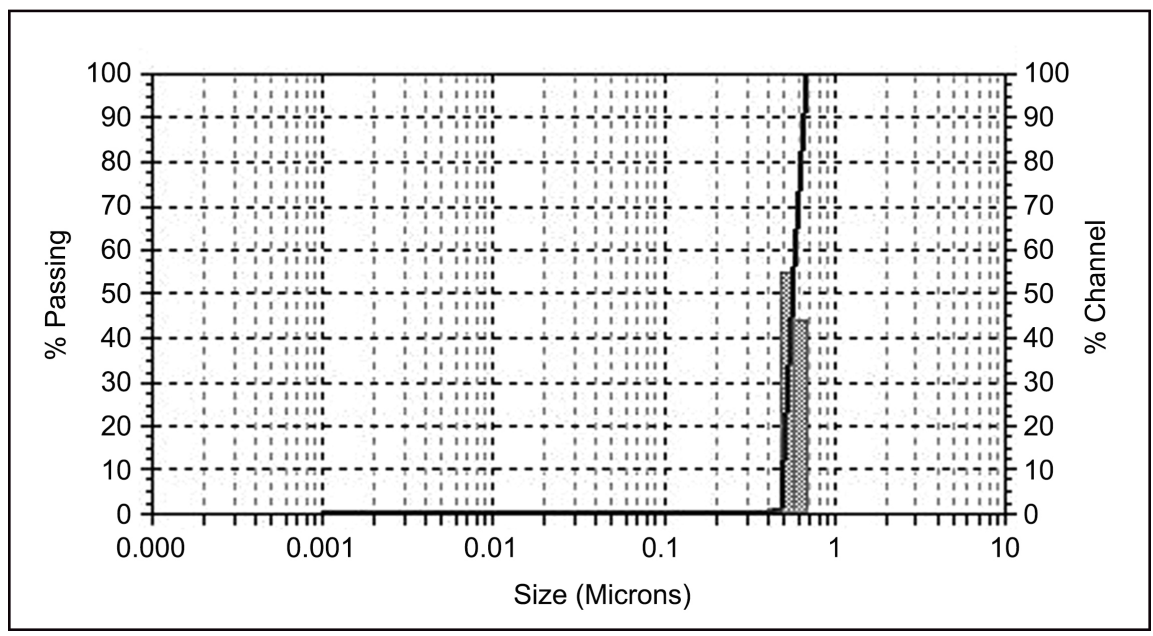

Figure 4. Particle size analysis test results of the Dead Sea mud samples (Table 3) from $[5]$. 
Table 3. Particle size analyses of the Dead Sea mud.

\begin{tabular}{cccccc}
\hline Sample No. & Skewness & Minimum \% & Maximum \% & Mean (Avg.) \% & $\begin{array}{c}\text { Standard } \\
\text { Deviation }\end{array}$ \\
\hline 1 & 0.11 & 0.573 & 0.57 & 0.56 & 0.05 \\
2 & 0.15 & 0.57 & 0.56 & 0.55 & 0.057 \\
3 & 0.066 & 0.578 & 0.57 & 0.56 & 0.06 \\
4 & 0.023 & 0.534 & 0.52 & 0.59 & 0.089 \\
5 & 0.1 & 0.64 & 0.633 & 0.62 & 0.058 \\
6 & 0.02 & 0.595 & 0.584 & 0.56 & 0.082 \\
7 & 0.058 & 0.63 & 0.613 & 0.59 & 0.08 \\
\hline
\end{tabular}

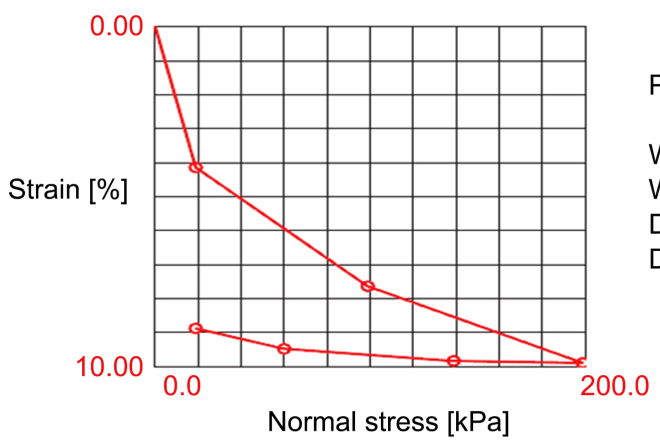

Parameters of sample:

Water content before test: $38.7 \%$

Water content after test: $34.87 \%$

Density before test: $1.932 \mathrm{~g} / \mathrm{cm}^{3}$

Density after test: $2.022 \mathrm{~g} / \mathrm{cm}^{3}$

\begin{tabular}{|c|c|c|c|c|c|}
\hline No. & $\begin{array}{c}\text { Normal } \\
\text { stress [kPa] }\end{array}$ & $\begin{array}{c}\text { Normal stress } \\
\text { change [kPa] }\end{array}$ & $\begin{array}{c}\text { Strain per } \\
\text { stage [\%] }\end{array}$ & $\begin{array}{c}\text { Strain } \\
\text { cumulativ [\%] }\end{array}$ & $\begin{array}{c}\text { Compression } \\
\text { modulus [MPa] }\end{array}$ \\
\hline 1 & 19 & 19 & 4.15 & 4.15 & 0.458 \\
\hline 2 & 99 & 80 & 3.50 & 7.65 & 2.191 \\
\hline 3 & 199 & 100 & 2.25 & 9.90 & 4.104 \\
\hline 4 & 139 & -59 & -0.05 & 9.85 & \\
\hline 5 & 60 & -78 & -0.35 & 9.50 & \\
\hline 6 & 19 & -40 & -0.60 & 8.90 & \\
\hline
\end{tabular}

Figure 5. Stress-strain diagram for the Dead Sea mud.

\subsection{Atterberg Liquid and Plastic Limits}

Liquid and Plastic Limit tests were carried out on the Dead Sea mud samples. The results are given in Figure 6, and show that the mud plots as medium plastic clay of illite composition and illite engineering properties. Also in Atterberg limits diagram DIN18122-1 [7], which correlates the Plasticity Limit (PI) with the Liquid Limit LL the mud plots as medium plastic clay TM [5].

\subsection{Shear Strength Analyses}

Shear strength analyses were carried out on the Dead Sea samples [12] (Figure 7). The results give an internal friction angle of $28.15^{\circ}$ and a low cohesion of 9.33 $\mathrm{kN} / \mathrm{m}^{2}$. 


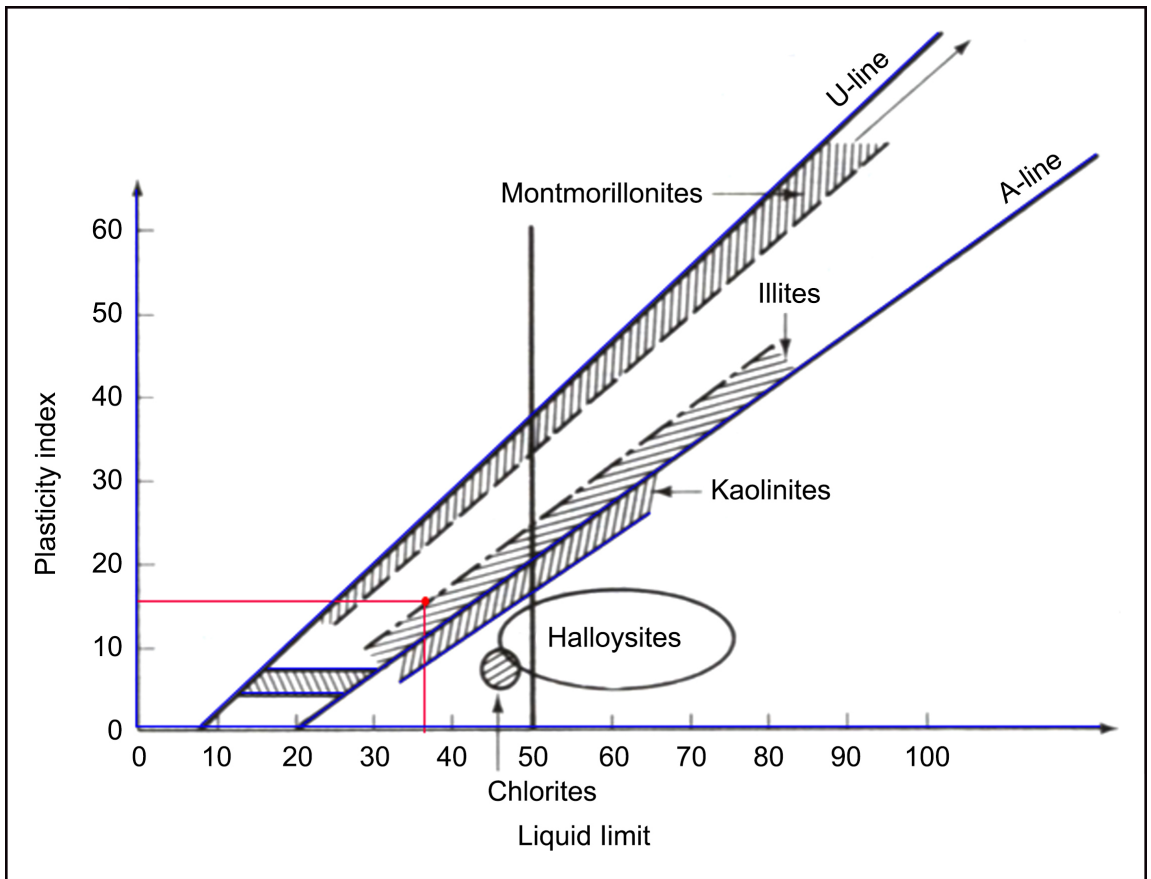

Figure 6. Liquid and Plastic Limits plotted to determine the types of clays in the samples. The Dead Sea mud plots here between A and U lines, in the illite range.

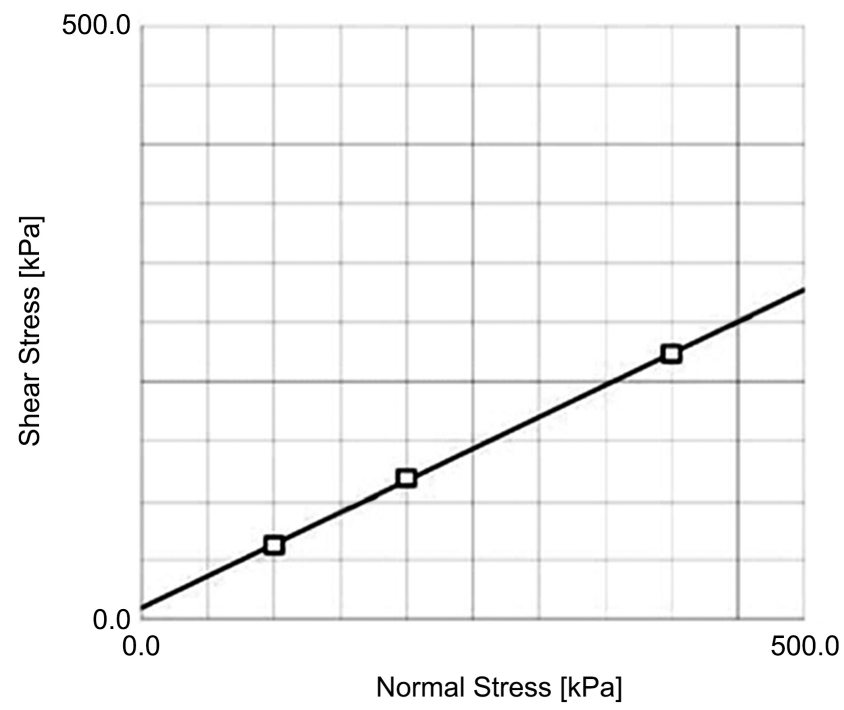

Shear Parameters

\begin{tabular}{|c|c|}
\hline Froction Angle & $28.15\left[^{\circ}\right]$ \\
\hline Cohesion & $9.33\left[\mathrm{kN} / \mathrm{m}^{2}\right]$ \\
\hline Corrlation & 1.00 \\
\hline
\end{tabular}

\begin{tabular}{|c|c|c|c|}
\hline Nr. & Normal Stress $[\mathrm{kPa}]$ & Shear Strength $[\mathrm{kPa}]$ & $\begin{array}{c}\text { Shear Path at } \\
\text { Faiture }[\mathrm{mm}]\end{array}$ \\
\hline 1 & 400.0 & 222.79 & 6.34 \\
\hline 2 & 200.0 & 118.02 & 6.37 \\
\hline 3 & 100.0 & 61.71 & 4.37 \\
\hline
\end{tabular}

Figure 7. Normal stress/shear stress diagram for the Dead Sea mud samples. 


\subsection{Permeability Test}

The permeability tests on the Dead Sea mud performed at Halle University/Germany using the variable-head permeability test) show that the Dead Sea mud has very low permeability of $4.7 \times 10^{-9} \mathrm{~m} / \mathrm{s}$ [5]. This means that the mud is not easily and fast enough drained of water. When the Dead Sea level drops the mud becomes exposed at ground surface and the water in the mud becomes over-pressurized. Here the developed internal pressure assists in cracking the mud and in the drying of the new cracks' surfaces [13] [14] [15].

\subsection{Landslide Analysis}

Along all wadis incised into the mud formation landslides and land collapses are very common (Figure 8 and Figure 9).

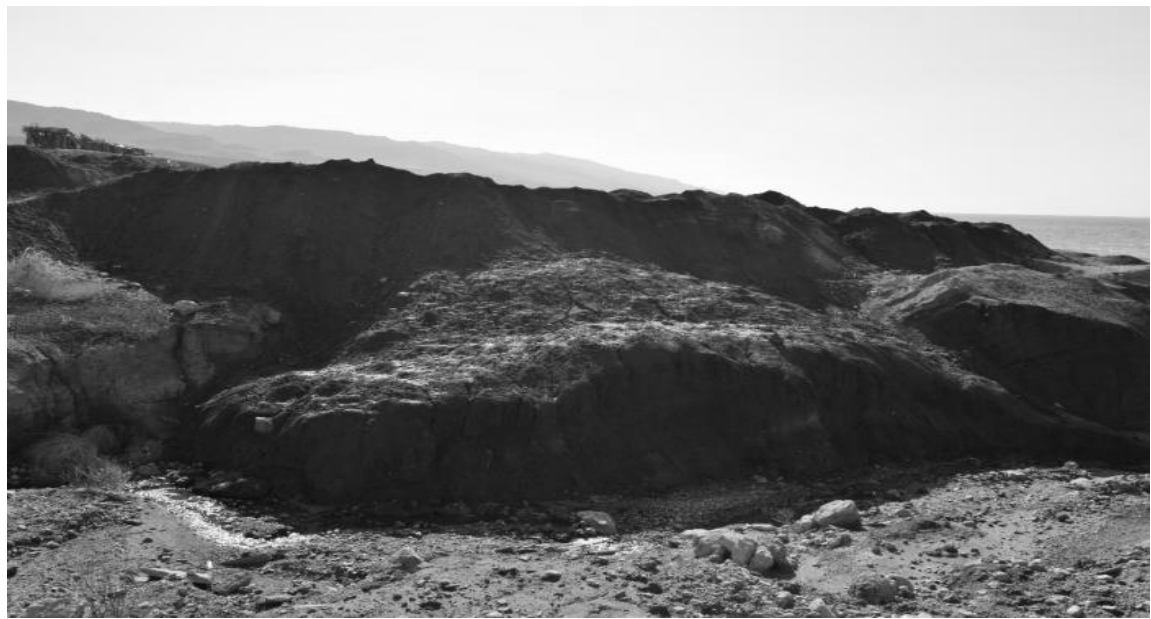

Figure 8. Front view of one of one of the landslides in the study area.

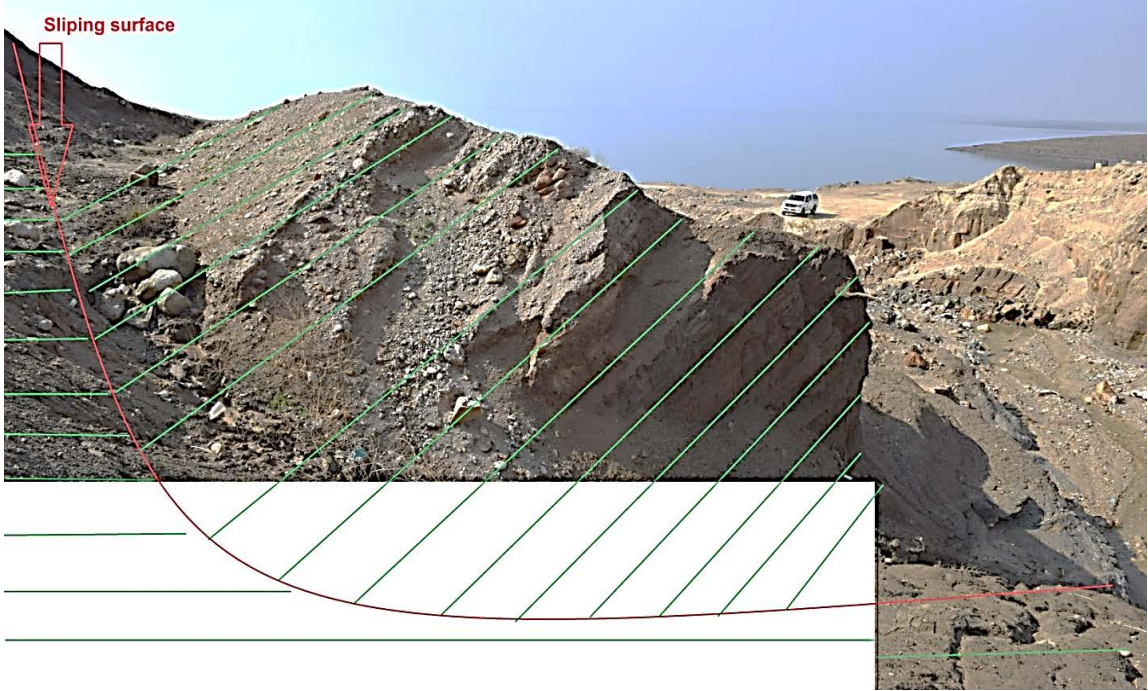

Figure 9. Side view of one of the landslides in the study area. 


\subsection{Factor of Safety}

Two methods were used to determine the factor of safety (FS) in the study area [16].

1) Moment equilibrium: $\mathrm{FS}=\mathrm{Mr} / \mathrm{Md}$

Where Mr: is the sum of resisting moments and Md: is the sum of driving moments.

By using the engineering test results of: Shear strength analyses, Atterberg Liquid and Plastic Limits, Stress-strain and permeability tests it was found that the driving forces equal $1220.45 \times 10^{3} \mathrm{~N}$ and the resistive forces to equal 718.41 $\times 10^{3} \mathrm{~N}$ and hence $\mathrm{FS}=0.588$ which is less than one indicating unstable slopes.

2) Force equilibrium: $\mathrm{FS}=\mathrm{Fr} / \mathrm{Fd}$

Where Fr: is the sum of resisting force and Fd: is the sum of driving force. Here it was found that the driving force $=208.9 \times 10^{3} \mathrm{kN}$ and the resistive force $=102.63 \times 10^{3} \mathrm{kN}$ and hence, FS $=0.49$ which is less than one also indicating unstable slope.

\subsection{Erosion and Destruction}

At present the DS level drops more than one meter per year with a total drop from the 1960s until now of about $35 \mathrm{~m}$. This drop has led to dramatic changes and destruction in the surrounding geomorphic system, especially in the wetland environments which has and is endangering the natural environment and the infrastructure. Severe erosion and undercutting is affecting wadi channels, roads, culverts and construction as can be seen from Figure 10 and Figure 11.

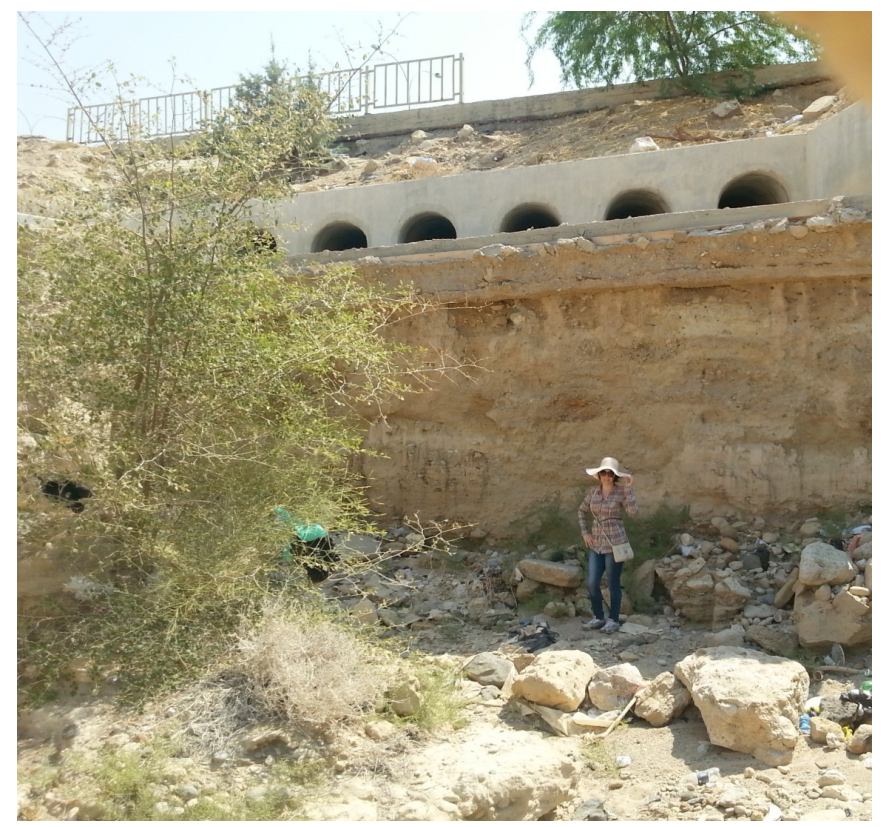

Figure 10. Head-ward erosion along one of the wadis in the study area. It has reached the main road built along the Dead Sea, which shore lies now at around $600 \mathrm{~m}$ west of that main road. The height (thickness) of eroded materials is around $5 \mathrm{~m}$ and erosion has started to excavate the rocks underlying the main road. 


\section{Engineering Geological Solution}

Engineering geological solution can assist in alleviating the degradation processes along the recently exposed areas as a result of retreating Dead Sea shores. Such solutions cannot be applied all over the area and for all types of degradation. Therefore, for each area and problem specific solution has to be found such as:

- Changing the geometry of the slope in some areas

- Providing adequate drainage

- Constructing retaining walls with proper drainage

- Construction of reinforced concrete walls

- Building of gabion walls and terraces. Figure 12 terraces and gabions constructed by one of the hotels to alleviate the degradation processes and to stop erosion.

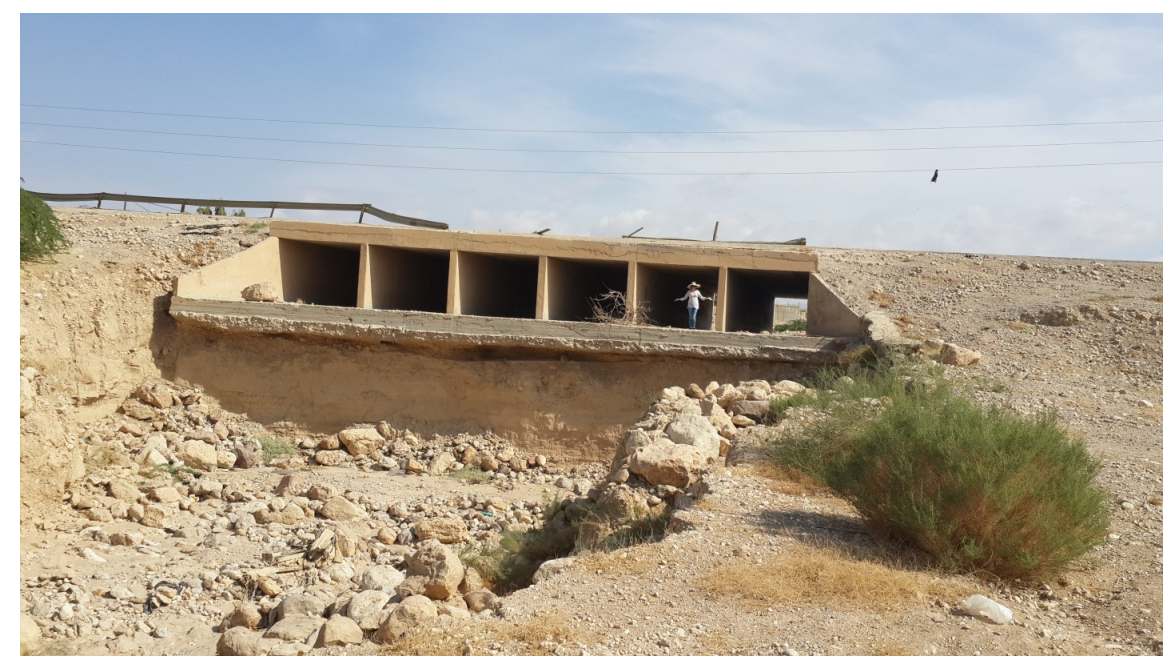

Figure 11. Severe undercutting and erosion affecting the foundation of the main Dead Sea road culvert, by now threatened to collapse.

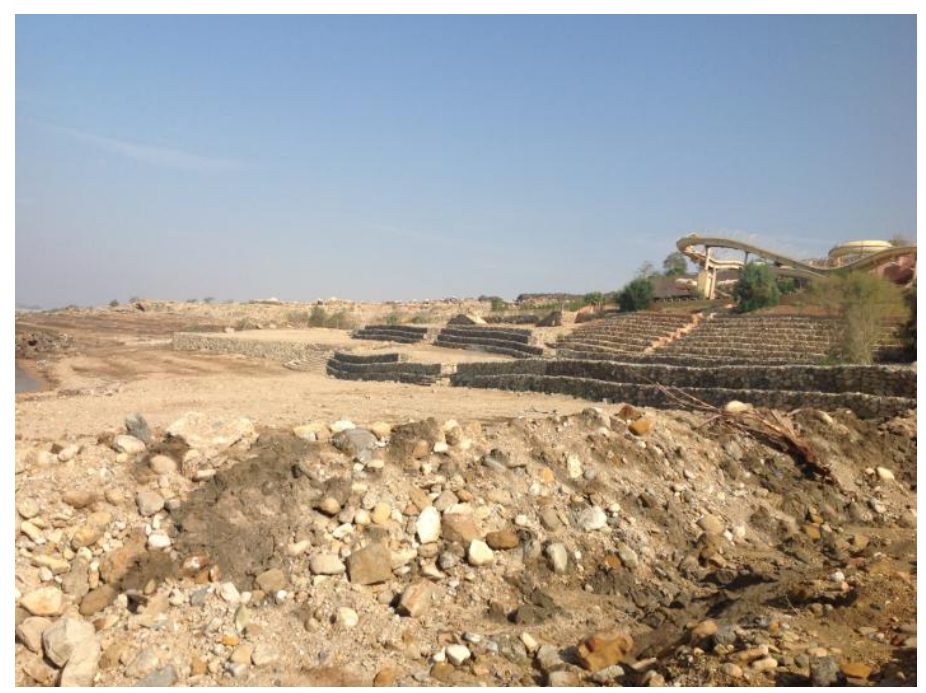

Figure 12. Gabion walls and terraces as a solution to the erosion problem in the newly formed terraces' areas which have been evacuated of Dead Sea water. 


\section{Summary of Results}

Due to lowering of the DS level new land built of two main types of sediments has been exposed namely; coarse gravels underlain by fine-grained mud and consolidated and stable country rocks. The recent sediments of the shores of the Dead Sea are not consolidated and are strongly exposed to erosion and back-ward erosion along wadis, which in turn leads to land collapses and landslides [17].

Mud deposits at the shores of the Dead Sea are the most vulnerable to such erosional processes and therefore, their mineralogical, hydraulic and geotechnical properties have been the focus of this study with the following results:

- XRD, XRF and SEM analyses show that the samples contain quartz, calcite, halite, kaolinite, smectite (montmorillonite), illite, gibbsite, and muscovite and are rich in organic matter.

- The black mud deposits seem to originate from the weathering, erosion, transportation and deposition of older country rocks composed of oil shale which used to cover the surrounding eastern mountains before they were removed by erosion and deposited in the study area.

- The geotechnical tests show that there is no compression history for the sample with a natural water content of $37.9 \%$ that means it is already in the liquid state and can flow by any triggering factor.

- Engineering geological tests show that the mud has a grain sizes ranging from 0.98 to $3.9 \mu \mathrm{m}$, is of very low permeability of $4.7 \times 10^{-9} \mathrm{~m} / \mathrm{s}$, witha plasticity limit of $21.8 \%$ and a liquid limit of $37.9 \%$. The internal friction angle measures $28.15^{\circ}$ and the cohesion $9.33 \mathrm{kN} / \mathrm{m}^{2}$, which allow the sample to plot in the illite range of medium plastic clay.

- Undercutting along the Dead Sea shores and the wadi courses has created instability in the slopes causing their collapses as landslides or rock toppling initiated by shrinkages of the excavated mud deposits due to moisture content losses and formation of deep mud cracks. This all has been assisted by the type of medium plastic clay of illite geologic engineering properties.

- Head-ward erosion along the wadis has created steep slopes, which has started to severely affect the infrastructure of roads, culverts construction etc.

- Engineering geologic solutions to the degrading geology has become imperative in the case of the northeastern shores of the Dead Sea.

\section{Conclusions}

The retreat of the DS exposed unstable new coastal areas which, before, were under sea. The black muds are generally of horizontal bedding as exposed along wadis which deepened their curses by head-ward erosion due to the drop in the level of the DS. Land collapses and landslides developed and strongly affected the sides of wadis and areas at the DS shores, threatening herewith the infrastructure of roads, bridges and buildings.

Drying of surface exposures of the black mud reduces the water content to below the plasticity limit of $21.8 \%$, causing vertical crakes in these surface expo- 
sures. The very low permeability of the mud accompanied by fast drop in the Dead Sea level created water over-pressure within the mud helping here within the formation of deep cracks in the mud which, assisted with wadi courses deep incisions by erosion, have led to sliding processes and rock toppling.

At present, the area is strongly suffering of geologic degradation which is causing damage to the environment and to the infrastructure in the area.

Unless immediate solutions are applied to alleviate the impacts, catastrophes are awaiting the area in the form of road and building damages.

\section{Acknowledgements}

The authors would like to extend their sincere thanks to Dr. Stefan Geyer, University of Halle, Germany for his help in analyzing the rock samples and for his support and constructive suggestions.

\section{Conflict of Interest}

Both authors declare that there is no conflict of interest regarding the publication of the present manuscript.

\section{References}

[1] Salameh, E. and Nasser, H. (1999) Does the Actual Drop in Dead Sea Level Reflect the Development of Water Sources within Its Drainage Basin? Acta Hydrochimica et Hydrobiologica, 27, 5-11. https://doi.org/10.1002/(SICI)1521-401X(199901)27:1<5::AID-AHEH5>3.0.CO;2-Z

[2] Salameh, E. and Nasser, H. (2005) Retreat of the Dead Sea and Its Effects on the Surrounding Groundwater Resources and the Stability of Its Coastal Deposits. In: Hoetzl, H., Ed., Sustainable Use of Water Resources along the Lower Jordan River, Springer, Berlin, Heidelberg, 247-264.

[3] AbouKaraki, N., Closson, D., Salameh, E., de Schoutheete de Tervarent, M. and Barjous, M. (2005) Natural, Induced and Environmental Hazards along the Dead Sea Coast, Jordan. Journal of Hydrogeology and Environment, 33, 1-25.

[4] Filin, S., Avni, Y., Baruch, A., Morik, S., Arav, R. and Marco, S. (2014) Characterization of Land Degradation along the Receding Dead Sea Coastal Zone Using Airborne Laser Scanning, Geomorphology, 206, 403-420. https://doi.org/10.1016/j.geomorph.2013.10.013

[5] Salameh, E., Al-Raggad, M. and Amaireh, M. (2019) Degradation Processes along the New Northeastern Shores of the Dead Sea. Environmental Earth Sciences, 78, 164-173. https://doi.org/10.1007/s12665-019-8155-x

[6] DIN 18135 (German Industrial Norms) (2012) Soil-Investigation and Testing-Oedometer Consolidation Test.

[7] DIN 18122-1 (German Industrial Norms) (1997) Soil, Investigation and Testing-Consistency Limits Part 1: Determination of Liquid Limit and Plastic Limit.

[8] DIN 18130 (German Industrial Norms) (1998) Soil, Investigation and Testing-Determination of the Coefficient of Water Permeability Part 1: Laboratory Tests.

[9] (2015) Google Earth Maps, Landsat Images of Geomorphology. 
[10] Hunt, R.E. (2005) Geotechnical Engineering Investigation Handbook. 2nd Edition, Taylor \& Francis, Boca Raton, 1066 p.

[11] Folk, R.L., William, C. and Ward, W.C. (1957) Brazos River Bar: A Study in the Significance of Grain Size Parameters. Journal of Sedimentary Research, 27, 3-26. https://doi.org/10.1306/74D70646-2B21-11D7-8648000102C1865D

[12] Brook, N. (1993) The Measurement and Estimation of Basic Rock Strength. In: Hudson, J., Ed., Comprehensive Rock Engineering, Vol. 3, Pergamon Press, Oxford, 41-66. https://doi.org/10.1016/B978-0-08-042066-0.50009-4

[13] Hencher, S.R. and Knipe, R.J. (2007) Development of Rock Joints with Time and Consequences for Engineering. Proceedings of the 11th Congress of the International Society for Rock Mechanics, Vol. 1, 223-226.

[14] Hencher, S.R. (2011) Practical Engineering Geology. Applied Geotechnics Vol. 4, Taylor and Francis, Spon Press, New York. https://doi.org/10.1201/b12836

[15] Wyllie, D.C. and Mah, C.W. (2004) Rock Slope Engineering. 4th Edition, E \& FN Spon, London, 431.

[16] Blockley, D.I. (2011) Engineering Safety. Proceedings of the Institution of Civil Engineers: Forensic Engineering, 164, 7-13. https://doi.org/10.1680/feng.2011.164.1.7

[17] Ollier, C.D. (2010) Very Deep Weathering and Related Landslides. In: Calceterra, D. and Parise, M., Eds., Weathering as a Predisposing Factor to Slope Movements, Geological Society, London, Engineering Geology Special Publications 23, 5-14.

https://doi.org/10.1144/EGSP23.2 